\title{
Pre-Service Teacher Training in Mathematics Using Tablet PC Technology*
}

\author{
Olga KOSHELEVA \\ University of Texas at El Paso \\ 500 W. University Ave, El Paso, TX, 79968 United States \\ e-mail: olgak@utep.edu
}

\author{
Ana MEDINA-RUSCH \\ University of Georgia \\ 105 Aderhold Hall, Athens, GA 30602 United States \\ e-mail:anarusch@uga.edu \\ Vera IOUDINA \\ Department of Statistics, University of California at Los Angeles \\ 8125 Math Sciences Building, Box 951554 Los Angeles, CA 90095-1554 United States \\ e-mail:vioudina@stat.ucla.edu
}

Received: January 2007

\begin{abstract}
This study focuses on the use of innovative Tablet PC technology in learning and teaching mathematics. Specifically the effects of incorporating Tablet PC technology in pre-service teachers' mathematics education were analyzed. The significant impact of technology use in mathematics education was assessed by evaluating and comparing students' final project and course grades. Grade performance of two groups of students was compared. One group was the treatment group where students extensively used Tablet PCs to work on mathematical investigations and explorations and to create lesson plans and animated games through PowerPoint presentations. The other group was the control group where students worked on identical mathematics investigations and created lesson plans without utilizing any technology. The outcome shows that the technology enhanced group achieved significantly higher scores than the control group. This outcome indicates a greater improvement in the treatment group's understanding of mathematical content versus that of the control group's.
\end{abstract}

Key words: technology for teaching and learning, mathematics education, digital divide.

\section{Introduction}

To benefit from computers teachers should have access to good educational software and be familiar with the available software. Ideally teachers should be able to use appropriate software to create math activities that guide students to higher order thinking.

* This work was supported by Teachers for New Era minigrant, which is part of the TNE grant from the Carnegie Corporation of New York. 
Pre-service (future) teachers should be confident and knowledgeable about effective instructional strategies that incorporate technology including those available using Tablet PCs.

In the beginning of 2004 the team of researchers from the College of Education and College of Engineering at the University of Texas at El Paso (UTEP) received a grant from Hewlett Packard.

This grant allowed UTEP to organize a mobile Tablet PC lab. This lab was readily available for use in the mathematics content and mathematics methods classes taught in a field-based environment. It was this HP grant which provided us the necessary technology for this study.

\section{Methodology}

In spring semester of 2005, 38 pre-service elementary teachers were enrolled in mathematics content and mathematics methods courses. These students were also enrolled in internships at local elementary schools. The students' internships and class placement was random.

The study focused on two groups of students. The treatment group consisted of fifteen students that regularly met in a professional development school where they were provided with 14 Tablet PCs for use in their classes. The control group consisted of 23 students who were enrolled in the same courses with the same instructors but met at different times and location. In this control group Tablet PC technology was not used. The method used in teaching pre-service teachers from the control group will be called in this paper standard inquiry based method.

One of the primary goals of the senior-level undergraduate mathematics and mathematics methods courses is to provide capstone-type mathematics classes for future teachers, and significantly increase students' understanding of the mathematics concepts and mathematics pedagogy. The main reason why these two classes are offered together (back to back) is to provide intrinsic connection between abstract mathematics concepts and mathematical pedagogical practices. The scheduling also provided great opportunity to organize team-teaching of these classes.

\subsection{Rationale for Proposed Intervention}

Research findings (Mariotti, 2002; Hoyles and Noss, 2003) supporting the use of innovative technology in teaching mathematics show that it:

- may help students to

- deal effectively with multiple representations

- learn how to formulate and test hypotheses;

- learn to visualize difficult mathematical concepts;

- constructively build their own knowledge;

- create and experiment with mathematical models; 
- further develop problem-solving abilities;

- enhances ability of students to focus on the process of problem solving instead of the computational aspect, thus decreasing dependence on procedural aspects of mathematics;

- provides an opportunity to introduce mathematically interesting/challenging problems much earlier than in traditional mathematical classroom;

- can also provide immediate feedback that allows students to discover their mistakes, analyze them and correct them; in this way, errors stop being obstacles, and may become a gateway to meaningful learning;

- encourages explorations and investigations with the use of dynamic software tools.

\subsection{Description of the Intervention}

All mathematics content and mathematics methods classes were team taught using a series of rich mathematical investigations, in-depth discussions on topics in the methods textbook (Van de Walle, 2004) and group lesson preparations and implementations. Specifically, these courses were designed to foster conceptual understanding of mathematics and pedagogy in the following major strands: rational numbers, geometry, algebra, number theory, and functions.

Rational numbers investigations dealt with concepts such as equivalent fractions, meaningful operational algorithms and decimals. Geometry investigations dealt with the concepts of similarity, congruence, transformations, and the area versus length relationship. Number theory investigations dealt with place value, alternative bases and deconstructing operational algorithms while applying them to different bases. The investigation covering functions included linear and non-linear relationships as well as exploring multiple representations. All projects were designed to include open-ended problems that required thorough investigations to achieve successful solutions. Instructors utilized collaborative learning and inquiry based methodology while students worked in small groups.

The treatment group used Tablet PCs to explore the investigations or projects. This technology allowed students to explore each activity fully without being limited to paper and pencil drawings. The real time feedback in the various programs and websites used gave students a good evaluation tool of their problem solving methods. In addition, the ability to iterate calculations allowed students to focus on the "big" picture without getting bogged down with repetitive calculations.

Besides the rich investigations, students from both groups planned individual/group lessons and implemented them in local elementary schools. Students created these lesson plans by applying the concepts investigated in their mathematics content and mathematics methods courses. Students in the treatment group successfully implemented Tablet PCs in their individual and group teachings allowing pupils to engage in meaningful technology based activities. The following diagram illustrates the dynamic structure of the technology-enhanced mathematical classroom. 


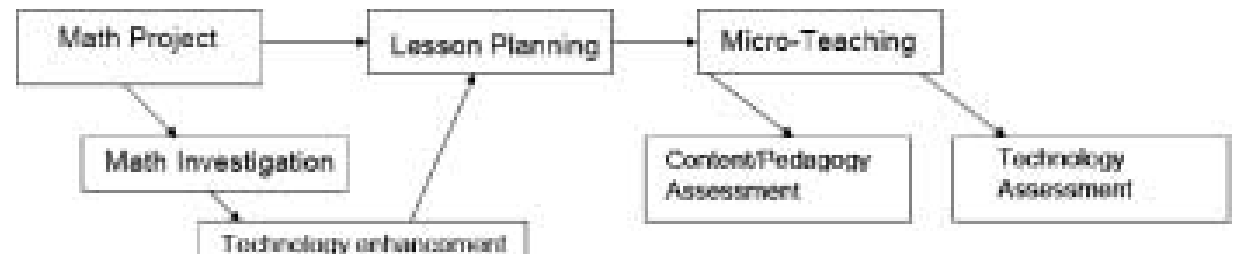

Fig. 1. Diagram describing pre-service teachers' integrated study of mathematics content and mathematical pedagogy in field-based context with technology enhancement (treatment group).

By the end of the four month period both groups had completed and presented several investigations. The students' final exam was an oral presentation covering the functions and algebra investigation.

The students' final grade was a cumulative grade indicative of the students' performances in each investigation, presentation, teaching and methods review.

\subsection{Implementing the Tablet PCs in a Technology-Enhanced Classroom}

Tablet PC's are fully functional PC's running an enhanced version of Windows XP Professional. One of their most interesting feature is the "digital ink" that allows a user to write on the screen using a stylus pen. The same pen is also used as a mouse. The handwriting recognition software allows the written text to be converted to digital text in Microsoft Word. Traditional keyboard and mouse are also available. Tablet PC's also have built-in wireless connectivity, so they can communicate with each other even if there is no internet connection present (ad hoc mode). They can also wirelessly connect to the internet. In newer Tablet PCs battery life can be up to six hours, however in our case our Tablets only had a battery life of three hours.

Students had the opportunity to utilize the Tablet PC during their presentations by connecting the Tablets to a data projector. In addition, since we had 14 Tablets and 15 students, students were able to work with the Tablet PCs individually or in small groups. Faculty used special software to communicate with the students.

First, using VNC software (http: / /www.realvnc.com/what.html) and internal wireless capability, faculty could connect to any of the students' Tablet PCs and check their work, help them and project their successful solution on the screen.

Second, Discourse software (www.ets.org/discourse) was used for the assessment. Using this software, faculty was able to ask various types of questions including open-ended or multiple-choice questions. Each question could be accompanied by an image guiding students to explore this particular question. In addition to images, faculty could guide students to a specific internet site relevant to the question. Students could answer their questions concurrently or on their own pace.

The faculty was also able to simultaneously monitor each student's answer in real time. Some of the students preferred typing the answers; others opened a writing pad, and recorded their answer on the pad. This writing pad automatically converted it to 


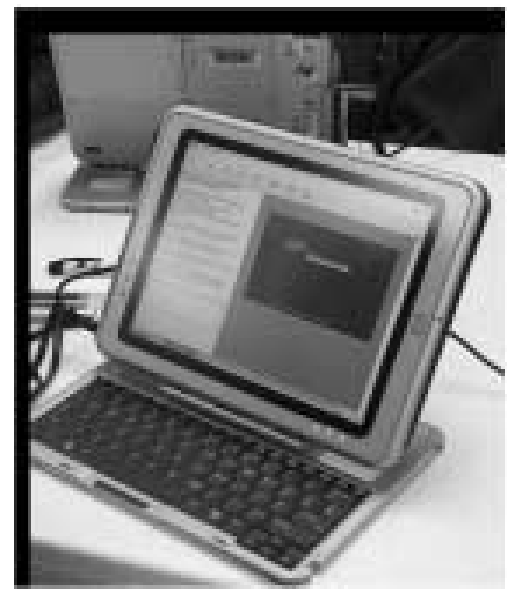

Fig. 2. Tablet PC screen showing Discourse session: questions are provided on the left part of the screen, image can be displayed on the right part of the screen.

digital text. Also, students could have discussions using the "chat" option (that can be disabled by faculty).

Pre-service teachers employed the Tablet PCs in their university courses and during their internship teaching in a number of ways. The most popular program was a program called Microsoft Journal, which comes free on Tablets and is used as an electronic whiteboard. The Power Point program was extensively used for presentations and for the creation of animated virtual manipulatives. The students were very successful in creating virtual manipulatives for solving word problems, place value tasks, fractions, and geometrical designs. Similarly, Kidspiration and Inspiration (http: //www.inspiration.com/) software was used for the creation of mathematical activities and games. Students also used this software to create concept or mind maps.

Variety of specialized free software was also used. One of the most interesting software was Java Bars (http: //tt.uga. edu/tt/jwilson. coe.uga. edu/olive/ welcome. $\mathrm{html}$ ) that provides a creative workspace to explore fractions. Tangram editor was also extensively used.

Excel was used in mathematical projects by utilizing the different spreadsheet capabilities such as graphing and formula calculator. Another interactive site used for fractions was Cynthia Lainus' website (http://math.rice.edu/ lanius/Lessons/) from Rice University where students could explore fractions with pattern blocks.

Students also used a variety of internet sites such as the National Library of Virtual Manipulatives (http://nlvm.usu.edu/en/nav/vlibrary.html), NCTM Illuminations (http://illuminations.nctm.org/), Math Playground (http:// www.mathplayground.com/) and InterMath Investigations (http://intermath. coe.uga.edu/). Pre-service teachers used a WebCT portal provided to all students by the university to submit their work for grading and discussion as well as for submitting questions outside of class time. 


\section{Results}

\subsection{Formative Assessment}

We assessed the progress of the pre-service teachers from both groups throughout the semester using grades from Projects (one and two), Quiz \#1 (only one quiz was given), teaching observations, and students' reflections.

We computed students' grade point average (GPA) using only their previous mathematics courses they have taken. This information provided us with good estimation of their initial mathematical knowledge. Typically, pre-service teachers enrolled in our program do not have very strong mathematical background. Specifically, the average math GPA computed for the treatment group was 2.99, and the average math GPA for the control group was 2.98 . This indicated that both groups had approximately the same mathematical background and content knowledge prior to the study. Fig. 3 shows comparative performance of both groups on Project \#1. As we can see, pre-service teachers from control group demonstrated better performance (more A grades, and the average grade is higher, as shown in Table 1).

Figs. 4, 5, 6 and 7 and Table 1 show that the situation changed, and starting with Project \# 2 pre-service teachers from treatment group demonstrated much better performance.

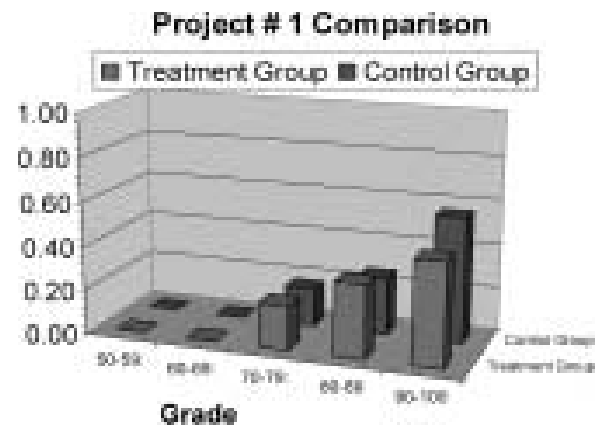

Fig. 3. Comparison of the treatment and control group based on the grades from math Project 1.

Table 1

Average grades for treatment and control groups (throughout the semester)

\begin{tabular}{lccccc}
\hline & Project \#1 & Project \#2 & Quiz \#1 & Final Exam & Final Grade \\
\hline Treatment Group & 86.1 & 93. & 71.7 & 90.8 & 93 \\
Control Group & 89.5 & 88.7 & 59.7 & 84.9 & 87.7 \\
\hline
\end{tabular}




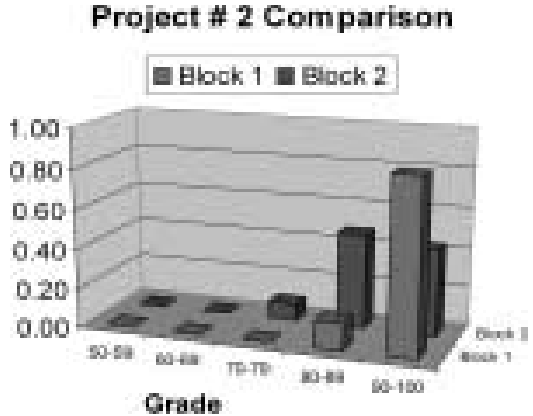

Fig. 4. Comparison of the treatment and control group based on the grades from math Project 2.

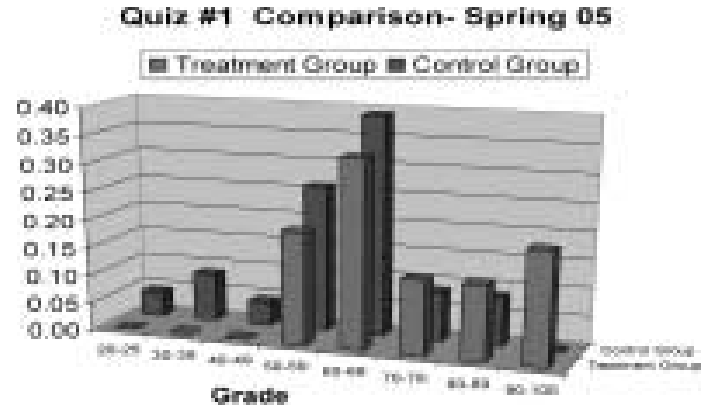

Fig. 5. Comparison of the treatment and control group based on the grades from math Quiz 1.

\section{Final Project Comparison-Spring 05}

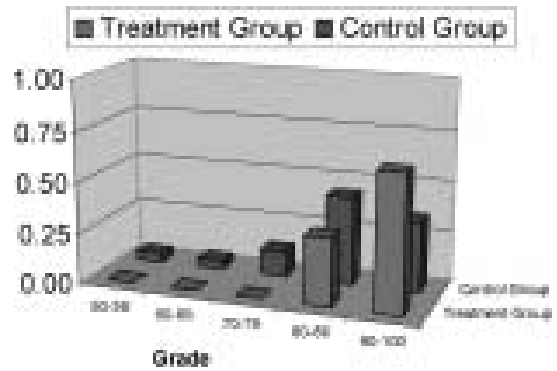

Fig. 6. Comparison of the treatment and control group based on the Final Project grades.

\subsection{Statistical Results}

The effectiveness of the proposed technology enhancement for teaching mathematics was statistically compared to the standard inquiry based method. This comparison was based on the results of two distinct items. The first was the students' Final Exam given at the end of a 4 month learning period. The second was the students' Final Grades which is a cumulative grade based on all the investigations throughout the semester. Of a random sample of 38 students, 15 were taught by the technology enhanced method and were considered 


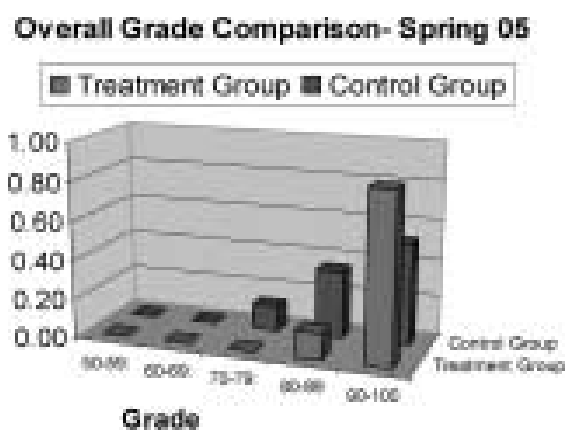

Fig. 7. Comparison of the treatment and control group based on the Overall grades.

our treatment group. The other 23 students were taught by the standard inquiry-based method and were considered our control group. All 38 students were taught by the same qualified instructors under similar conditions.

As was mentioned before, students' grade point average (GPA) was computed using only their previous mathematics courses. The average math GPA for the treatment group was 2.99 while the average math GPA for the control group was 2.98 . This means that both groups had approximately the same mathematical background and content knowledge prior to the study. We developed descriptive statistics for both samples and both teaching methods see (Table 2).

Based on our observations during the previous semesters, we expected that the new teaching method would be more effective. If we could show a statistically significant difference between these groups, we could conclude this observation to be valid. To do this, we have set up a null hypothesis that the two sample means were the same (or the two groups come from the same population), and attempted to reject that hypothesis.

The standard approach for this situation is to use the small-sample $t$-test. The first theoretical assumption about the independency of observations was satisfied, based on the information provided about the sampling procedure. The second assumption was about Normality. As we can see in Figs. 8 through 11, the histograms of all four distributions are bell-shaped and approximately symmetric.

To verify the Normality in more rigorous way, we used the $\chi^{2}$-test for the Final Exam

Table 2

Sample's descriptive statistics

\begin{tabular}{lccccccccc}
\hline \multirow{2}{*}{ Group } & \multicolumn{4}{c}{ Final Exam } & & \multicolumn{4}{c}{ Final Grade } \\
\cline { 2 - 4 } \cline { 7 - 9 } \cline { 6 - 8 } & $n$ & Mean $\bar{X}$ & $\operatorname{Var} \sigma^{2}$ & St.Dev. & & Mean $\bar{X}$ & Var $\sigma^{2}$ & St.Dev. \\
\hline $\begin{array}{l}\text { Treatment } \\
\text { Group 1 }\end{array}$ & 15 & 90.8 & 14.31 & 3.78 & & 15 & 93.04 & 8.95 & 2.99 \\
\hline $\begin{array}{l}\text { Control } \\
\text { Group 2 }\end{array}$ & 23 & 84.9 & 77.55 & 8.81 & & 23 & 87.70 & 42.49 & 6.52 \\
\hline
\end{tabular}




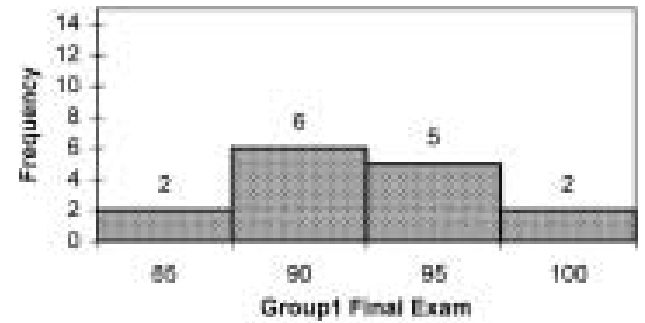

Fig. 8. Distribution Histogram for the treatment group's Final Exam.

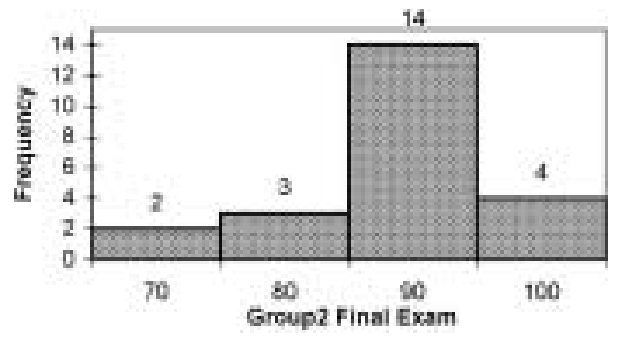

Fig. 9. Distribution Histogram for the Control group's Final Exam.

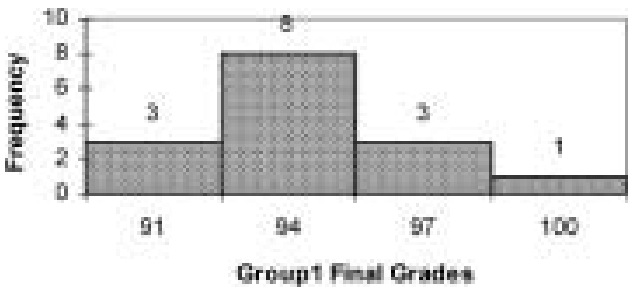

Fig. 10. Distribution Histogram for the treatment group's Final Grades.

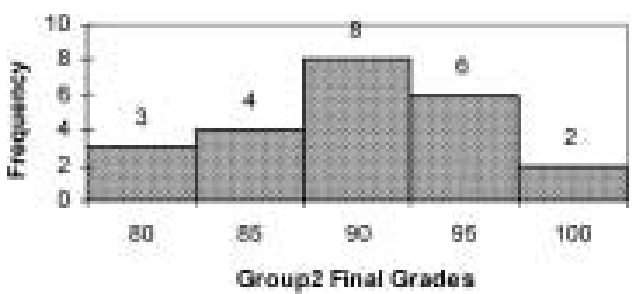

Fig. 11. Distribution Histogram for the control group's Final Grades.

and Final Grades for both groups. The results of four tests are represented in Table 3.

The test shows that for all four distributions the calculated value chi-square was less than the critical value for the indicated degrees of freedom and $\alpha$. There was insufficient evidence to reject the null-hypothesis about the Normal distribution for given samples. Consequently, each sample data set appeared to come from a population that is 
Table 3

The Results for $\chi^{2}$-test for Final Exam and Final Grades

\begin{tabular}{lccccc}
\hline \multicolumn{6}{c}{ Final Exam } \\
\hline Group & $n$ & $\chi^{\mathbf{2}}$ & $\boldsymbol{d} f$ & $\boldsymbol{\alpha}$ & $\chi_{\text {critical }}^{\mathbf{2}}$ \\
\hline $\begin{array}{l}\text { Treatment } \\
\text { Group 1 }\end{array}$ & 15 & 3.53 & 1 & 0.05 & 3.84 \\
\hline $\begin{array}{l}\text { Control } \\
\text { Group 2 }\end{array}$ & 23 & 4.37 & 1 & 0.025 & 5.02 \\
\hline & & & & & \\
\hline Group & $n$ & $\chi^{\mathbf{2}}$ & $\boldsymbol{d f}$ & $\boldsymbol{\alpha}$ & $\boldsymbol{\chi}_{\text {critical }}^{\mathbf{2}}$ \\
\hline $\begin{array}{l}\text { Treatment } \\
\text { Group 1 }\end{array}$ & 15 & 1.52 & 1 & 0.05 & 3.84 \\
\hline $\begin{array}{l}\text { Control } \\
\text { Group 2 }\end{array}$ & 23 & 0.78 & 2 & 0.05 & 5.99 \\
\hline
\end{tabular}

approximately Normal. Moreover, as we know, the $t$-test is robust to moderate departures from Normality.

The third and weaker assumption was that the two samples come from distributions with approximately the same variance.

For our samples we could see that the ratio of the larger to smaller standard deviation was greater than two, therefore the unequal variance test had to be used. In the case where the sample sizes and variances are different $\left(\mathrm{n}_{1} \neq \mathrm{n}_{2}\right.$ and $\left.\sigma_{1}^{2} \neq \sigma_{2}^{2}\right)$, an approximate small-sample test could be obtained by modifying the standard deviation and the degrees of freedom associated with the $t$-distribution.

We used the Approximate Small-Size Procedure (McClave and Sincich, 2003, p. 390; Devore, 2004, p. 373) when $\sigma_{1}^{2} \neq \sigma_{2}^{2}$.

We let $\mu_{1}$ and $\mu_{2}$ represent the population mean for the Final Grade of the treatment and control groups, respectively. The null hypothesis $H_{0}:\left(\mu_{1}-\mu_{2}\right)=0$ signified that samples do not differ significantly. The alternative hypothesis was $H_{1}:\left(\mu_{1}-\mu_{2}\right)>0$.

Test statistic is $t=\frac{\bar{X}_{1}-\bar{X}_{2}}{\sqrt{s_{1}^{2} / n_{1}+s_{2}^{2} / n_{2}}}$, where $t$ is based on degrees of freedom equal to

$$
d f=\frac{\left(s_{1}^{2} / n_{1}+s_{2}^{2} / n_{2}\right)^{2}}{\frac{\left(s_{1}^{2} / n_{1}\right)^{2}}{n_{1}-1}+\frac{\left(s_{2}^{2} / n_{2}\right)^{2}}{n_{2}-1}} .
$$

The test results are represented in Table 4 . Table 4 shows that the $t$-values for both tests are much bigger than the critical value of the $t$-test with the 5\% Type I Error. The table of $t$-distribution (Devore, 2004, p.747) shows that the area under the 32 degrees of freedom $t$-curve to the right of 2.851 for the Final Exam test is 0.0035 . So the $p$-value for the upper-tailed test is also 0.0035 , that corresponds to the probability $0.35 \%$. For the Final Grade test the $p$-value is only 0.001 or $0.1 \%$. 
Table 4

The results of the Small-Size $t$-test

\begin{tabular}{lcccccc}
\hline & \multirow{2}{*}{$\boldsymbol{t}$} & $\boldsymbol{d} \boldsymbol{f}$ & $\boldsymbol{\alpha}$ & $\boldsymbol{t}_{\text {critical }}$ & \multicolumn{2}{c}{ Confidence Interval } \\
\cline { 5 - 7 } & & & & & Lower limit & Upper limit \\
\hline Final Exam & 2.851 & 32 & 0.05 & 1.694 & 2.40 & 9.45 \\
Final Grade & 3.418 & 33 & 0.05 & 1.693 & 2.70 & 8.00 \\
\hline
\end{tabular}

With a confidence level 0.95 , we estimated the difference in the mean of the Final Exam scores between treatment group and the control group to fall in the interval (2.40, 9.45). This means that with $95 \%$ confidence we estimated the mean Final Exam score for the new method to be anywhere from 2.40 to 9.45 points more than the mean of the Final Exam score for the standard inquiry-based method.

The $95 \%$ confidence interval for the Final Grade is $(2.70,8.00)$, so we estimated the mean of the Final Grade for the new method to be anywhere from 2.70 to 8.00 points more than the mean of the Final Grade for the standard inquiry-based method. In other words, the new method was associated with higher mean scores.

Therefore there was enough evidence to indicate that $\left(\mu_{1}-\mu_{2}\right)$ differs from zero and that $\left(\mu_{1}-\mu_{2}\right)>0$. Using a significance level of 0.05 , we could reject the null hypothesis that the two sample means were the same in a favor of the alternative hypothesis which stated that the treatment group mean was significantly bigger then the control group mean for both, the Final Exam and the Final Grade.

Consequently, the statistical analysis of the data collected showed that the technology enhanced group achieved significantly higher mean scores than the control group. These higher mean scores obtained by the treatment group translated into the treatment group having a greater understanding of mathematics content when compared to the control group. This greater understanding could be directly contributed to the effective implementation of the Tablet PC technology in the mathematics content and mathematics methods courses. Thus, we simultaneously achieved two goals. We increased students' mathematics education software literacy and mathematics content knowledge.

\section{Conclusions and Discussions}

NCTM Technology Principle (NCTM, 2000) states: "Technology is essential in teaching and learning mathematics; it influences the mathematics that is taught and enhances students' learning".

Defining the role of teacher in using technology, it says: "The teacher must make prudent decisions about when and how to use technology and should ensure that the technology is enhancing students' mathematical thinking".

Use of digital technology in the classroom brings innovation. It also may ease the path to successful teaching for some categories of pre-service teachers, while create difficulties and obstacles for others. 
Our observations of pre-service teachers' interactions with computers have lead us to the conclusion that some of the future teachers already came from the generation of Digital Natives, while others certainly belong to Digital Immigrants (Prensky, 2001; Prensky, 2006). The proportion of these populations varied from semester to semester. Typical response of Digital Natives was “working with Tablet PCs was fun”, while typical Digital Immigrant would usually say that "working with Tablet PCs was a hard work, and I had to learn a lot about computers".

The technology-enhanced courses proved to provide a truly transformational experience for the pre-service teachers.

The greatest transformation was occurring in the affective domain. One good example was a student who came to our class with a fear of mathematics. At the end of class, she successfully taught a mathematical lesson using Tablet PCs in her internship classroom. She applied to a NASA Pre-Service Teacher Summer Institute at NASA Langley Education Research Center during June 2005, attended the Institute, and was awarded the best mathematics teaching award at the teaching competition held at the end of the program. She obtained the teaching position in one of the elementary schools, and she is currently pursuing her Master's degree in Mathematics Education. When asked about her experiences, she told that "math was never my strong subject". "I did not understand it, I did not like it". When asked how she survived high school math, she told that her sister helped her in all her classes.

Now, incorporation of technology in teaching and learning process changed a lot for her. She was using technology extensively in her everyday life. Therefore, when asked to teach and learn mathematics with the use of Tablet PC technology, she was not scared, but excited. She said that "we never have seen Tablet PC before, but we saw them, it was really cool, and we loved them". "When we actually got to use them with the students, and we would go to the schools and use them, the kids loved them (Tablet PCs, OK) even more. . . everything they did on Tablet PCs related to mathematics was like a game."

She says: "when I was exposed to math in a way you taught it, and the way we were learning it at NASA, I realized that it really is not that hard, as it was in my head. I am not much of an algebraic person, so trying to do math that way was really hard. When I was able to do it more physically (with manipulatives), and more conceptually, then I really liked it. Now I really want for students like me to be able to learn mathematics, and know that you can do mathematics in a lot of different ways".

This is just one example of a successful story. Here is another one.

Typically, pre-service teachers after their graduation have to take the standardized test to acquire teaching license certification. This test proved to be somewhat difficult for some of the students. Sometimes pre-service teachers take the test more than one time.

All the pre-service teachers from the treatment group were able to pass the test immediately after they graduated. The average total score for the treatment group was 259 , while the score for the mathematical domain questions was 269.5.

The situation was different for the control group students. Several of them took the test more than one time (one pre-service teacher had to take the test four times). The average total score for the control group (after everybody passed the test) was 232, and the score for the mathematical domain questions was 238.5 . 
These results once again confirm our conclusion that treatment group achieved a greater understanding of mathematics content when compared to the control group.

There are numerous changes brought by technology in teaching and learning environment. In the beginning the most focus was on the ability to do accurate computations faster. This is what Moursund (2002) has called first-order use of technology, that is, when we use technology to do what we can do already, but technology allows us do these things faster and more accurately. Now it is the time to address and focus on the second-order use of technology, i.e., local and global changes technology brings to different aspects of our society. In this work specific issues in mathematics education were addressed, and successful implementation of Tablet PCs technology was presented.

\section{References}

Devore, J.L. (2004). Probability and Statistics. 6th Edition. Thomson, NY.

Hoyles, C., and R. Noss (2003). What can digital technology take from and bring to research in mathematics education. In A.J. Bishop, M.A. Clements, C. Keitel, J. Kilpatrick and F.K.S. Leung (Eds.), Second International Handbook of Mathematics Education. Kluwer Academic Publishers, Dordrecht, pp. 323-349.

Mariotti, M.A. (2002). Influence of technologies advances on students' maths learning. In L. English, M. Bartolini Bussi, G. Jones, R. Lesh and D. Tirosh (Eds.), Handbook of International Research in Mathematics Education. Lawrence Erlbaum Associates, pp. 695-721.

McClave, J., and T. Sincich (2003). Statistics. 9th Edition. Prentice Hall, MA.

Moursund, D.G. (2002). Getting to the Second Order: Moving beyond Amplification Uses of Information and Communications Technology in Education. Learning and Leading with Technology, 30(1). Available at http://uoregon.edu/ moursund/dave/Article\&Presentations/second_order.htm NCTM (2000). Principles and Standards for School Mathematics. National Council of Teachers of Mathematics, Reston, VA.

Prensky, M. (2001). Digital natives, digital immigrants. On the Horizon, 9(5), 1-2.

Prensky, M. (2006). Listen to the Natives. Educational Leadership, 63(4), 8-13.

Van de Walle, J. (2004). Elementary and Middle School Mathematics: Teaching Developmentally. Pearson Education Press, NY.

O. Kosheleva received her MS degree summa cum laude in mathematics and applied mathematics from Novosibirsk University, Russia, in 1978. After coming to the USA in 1989, she received MS in computer science and $\mathrm{PhD}$ in computer engineering from the University of Texas at El Paso. In Russia, she participated in organizing mathematical olympiads for high school and middle school students, was actively involved in a special outreach program for teaching mathematics to high school students to better prepare them for the university studies, tutored university students in math, and taught mathematics and computer science to engineers. Since 2001, she is teaching at the University of Texas at El Paso. Her research interests include mathematics education in teacher preparation, embedding technology in learning, cognitive growth in elementary and advanced mathematical thinking, curriculum development, mathematics and applied mathematics. She has more than 40 journal publications, more than 60 papers in peer refereed conference proceedings, and more than 80 published conference abstracts. These publications cover different areas of mathematics education, mathematics and applied mathematics. 
A. Medina-Rusch received her $\mathrm{BChE}$ degree in chemical engineering from the Georgia Institute of Technology in Atlanta, Georgia in 1996. After working as a pulp and paper engineer for GL\&V/Celleco, she received her MS in mathematics education from the University of Georgia in 2003. She has taught in the Department of Mathematical Science at the University of Texas at El Paso from 2003 to 2006. More recently she has taught in the Math Department at Georgia Perimeter College from 2006 to 2007. She is currently at the University of Georgia completing her $\mathrm{PhD}$ in mathematics education. Her research interests include: pre-service teacher mathematics preparation, enhancing mathematics teaching and learning through the implementation of technology and teaching methods aimed at developing higher order thinking skills.

V. Ioudina received her MS degree in mathematics from Irkutsk State University, Russia, in 1977. She conducted her postdoctoral research at the Institute of Economics and Statistics in Moscow (Russia) with main focus on the robust estimation of the parameters of multiple linear regressions and got $\mathrm{PhD}$ in economics (statistical methods in economical researches) in 1985. V. Ioudina has taught in the areas of mathematics and statistics for almost twenty-five years at several universities in Russia, Mexico and the United States. Prior to coming to USA she lived in Mexico for three years and taught at the undergraduate and graduate levels at Monterrey Tech (known as the Tec de Monterrey) and at the Autonomous University of Ciudad Juarez. Since 2003 she has been working in the Department of Mathematical Science at the University of Texas at El Paso. Currently she is teaching at the Statistics Department of UCLA. Her main research interests fall within the field of applied statistics and data analysis. She participated in several collaborative research projects whose final product can be applied to social issues and educational improvements.

\title{
Būsimų matematikos mokytoju mokymas naudojant planšetinio kompiuterio technologija
}

\author{
Olga KOSHELEVA, Ana RUSCH, Vera IOUDINA
}

Šiame straipsnyje aptariamas tyrimas, nagrinejjantis planšetinio kompiuterio technologijos taikymą mokant ir mokantis matematikos. Svarbiausias dèmesys buvo sutelktas ị planšetinio kompiuterio technologijos poveiki studentu - būsimuju matematikos mokytoju mokymui. Technologijos poveikis matematikos mokymui buvo nustatytas ịvertinus ir palyginus mokiniu galutinị projekta ir mokymosi lygi. Atliekant tyrimą buvo lyginamos dvieju grupiu mokiniu žinios. Viena grupé buvo stebimoji grupe, joje mokiniai naudojo planšetinius kompiuterius atlikdami matematines užduotis ir rengdami namu darbus arba animuotus žaidimus naudodamiesi pateikčiu rengykle. Kita grupè buvo kontrolinė - jos mokiniai atliko tas pačias užduotis nesinaudodami jokia technologija. Hipotezė buvo patvirtinta: technologiją naudojanti grupé surinko daugiau taškų nei jos nenaudojanti. Taigi technologijos naudojimas turi didelę itaką matematikos supratimui ir išmokimui. 